\title{
The issues of urban green space in Baia Mare based on tree composition
}

\author{
Anna Imola HENNING \\ Szent István University Budapest, \\ Doctoral School of Landscape Architecture and Landscape Ecology \\ e-mail: henning_imola@yahoo.com
}

\begin{abstract}
Harmonious urbanization entails the creation of new green spaces and the rehabilitation of existing ones. Green spaces are not just spaces of psychic well-being but also social interaction sites. Present-day practice in redesign requires taking into consideration the ones using the spaces, in our case, the needs of urban residents, since space needs to have a crucial role in building and maintaining communities. This paper aims at drawing attention to conflicts regarding use mainly due to improper design and use of plant material and, in addition to the importance of green spaces, the need for quality green spaces.
\end{abstract}

Keywords: urbanization, green spaces, communities, quality green spaces

\section{Introduction}

The issue of urban green space (UGS) has become more and more common in research and planning as Europe and the United States play a leading role in the research on this topic [1]. This is not by chance as UGS has a great influence on the well-being of urban residents.

Rapid urbanization affects the spatial changes and influences the green spaces and historical spaces; the study and implementation of previous major planning strategies are essential to current planning. Furthermore, the availability of UGS is a crucial indicator of urban complexity, of improving the well-being of the residents, and of developing social and ecological relationships and interactions in towns and cities. The proportion of available surfaces and their quality is important in this process. According to Kabisch et al. [2], more than two-thirds of the inhabitants of Nordic countries and of the Western countries of the EU (Austria, North-West Germany) live less than 500 meters away from green spaces. While Poland, Slovakia, and the Czech Republic show good results in this respect, south- 
eastern European countries do somewhat worse: in Hungary, Romania, and Bulgaria, only $40 \%$ of the population lives up to 500 meters away from green spaces of at least 2 hectares large.

Baia Mare is a municipality located in the north-western part of Romania; it is the county seat of Maramureș. It has nearly 123,800 inhabitants, and it is the $17^{\text {th }}$ largest town in the country based on this number. It is most commonly known as a mining town. Since the closure of the majority of mines, mining towns in developing countries have shown a gradual decline, mainly due to economic reasons: the lack of new investments, the demographic aging of the population, and lack of culture.

Unlike other industrial and mining towns, Baia Mare is in a fortunate position due to its geographical location and spectacular tourist destinations, although the economic development and expansion that is needed has affected the environment, the surrounding nature, and the landscape. Another important distinctive criterion is the result of the existence and maintenance of the local spirit and culture.

It is commonly observed (similar to other locations in the country) that the holiday-type proliferation of buildings has had a disastrous impact on the landscape, which is further exacerbated by the lack of local infrastructure networks. There is a tradition of urban and closed gardens, which are often characterized by chaotic design; there is also a lack of public green spaces, while the existing ones are unprofessionally designed and are less appealing.

Undeveloped lands play an important role in the development of the town's image: there are key areas that count as the town's "green reserves". Building on these areas must be prevented, and there is need for the creation of a green network based on aggregation. The lack of "urban green" results in social and psychological problems; nevertheless, their improper maintenance, the poor and neglected green spaces also lead to the previously mentioned problems.

\section{Objectives}

UGS is an indicator of urban quality of life, it quantifies the physical, social, and economic characteristics of urban environments. Its purpose is multifaceted (ecological, functional, aesthetic, settlement-structure-oriented), wherefore it is important to deal with their condition and development.

The role of green spaces was significantly trimmed by the inadequate maintenance of green spaces that were periodically outlined during the development of urban free space by the lack of new, $21^{\text {st }}$-century uses, functions, and modern objectives of the free spaces designed based on former visions and principles, by the incorrect choice and poor use of plant material as well as the bleak view of smaller social spaces such as the green spaces around residential complexes. In the case of developing countries, there is a need to promote the 
importance of man-centred existing and newly designed green spaces and the benefits of using a variety of plant species.

Whatever used to work well in $20^{\text {th }}$-century urban planning (especially regarding the distribution and creation of free spaces), it is likely not to meet present-day needs, sustainable development, and, last but not least, ecological development. During my work, I call attention to the identification of aesthetic and functional conflicts as well as the poorness of vegetation use that characterizes the green spaces of Baia Mare.

\section{Materials and methods}

The first stage of the research was the identification of research sites: Fig. 1. I decided to work with four locations of different categories of use and function; the element these areas share is that they gradually lost their original purpose, their man-centredness, and aesthetic values over time. I study the sites based on their original purpose, their current use (comparing old postcards, photographs, and descriptions with the current use as well as performing on-site observation) together with the analysis of the used plant material. My aim is to draw attention to the direct impact on humans of UGS as well as the importance of quality and mancentred design:

Citizens contribute to the long-term management of urban green space. The activities and self-organization of citizens are highly dynamic over time. The adaptive capacity of citizen groups is essential in long-term place-keeping. Citizen groups can become institutionalized in order to ensure long-term continuity. Authorities are key in enabling and legitimizing place-keeping by citizens. [3]

The observation of green spaces was conducted between August 1, 2017 and September 15, 2017, during the weekdays and weekends.

\section{Results and discussions}

The taxonomy of UGS values is more complex: there are ecological, economic values (market value), social values (recreational value: utilization and function, aesthetic value, cultural symbolization value, historical value, therapeutic value, social interaction value, etc.), and the planning values. This value gives the scientific values (education function) and the policy value (financial and public function) [4]. The present study investigates the aesthetic, recreational effects of the research sites, values that affect quality of life, bearing in mind the taxonomical richness of the applied plant material increasing ecological diversity. In 
determining the quality of green spaces, the diversity of species is an important criterion and so is the proportion of built-up areas and green spaces, for which the highest value should be sought.

Three types of open-air activities are determined: necessary ones (throughout the year, in any circumstances, regardless of the external environment), optional ones (whenever external factors allow it), and social ones (quality environments have a great attraction value; thus, their use is intensive) [5]; at the same time, their distribution in the urban fabric is also important:

Living in areas with green environments has also been found to be related to health in more general terms: populations exposed to the greenest environments have the lowest levels of health inequality related to income deprivation (Mitchell \& Popham, 2008). The resurgent interest in ecologically rich urban green space has resulted in increased numbers of allotment tenants, the creation of community gardens and the active creation of green spaces through 'guerrilla gardening' . [6]

With the rapid development of the 1950s, the surface area of the town has been constantly growing: according to the General Urban Plan (PUG) from 2012 [7], there was a tenfold increase in the population between 1912 and 2002, which was followed by a downward trend. Based on the PUG, Baia Mare's administrative area is $23,262.81 \mathrm{ha}, 3,170$ ha of which is agricultural area, 18,599 ha is forestry area with mostly forests, while 1,804 ha are built in or have other functions. $76.83 \%$ of the periphery is made up of forests. The size of green spaces is close to 100 hectares.

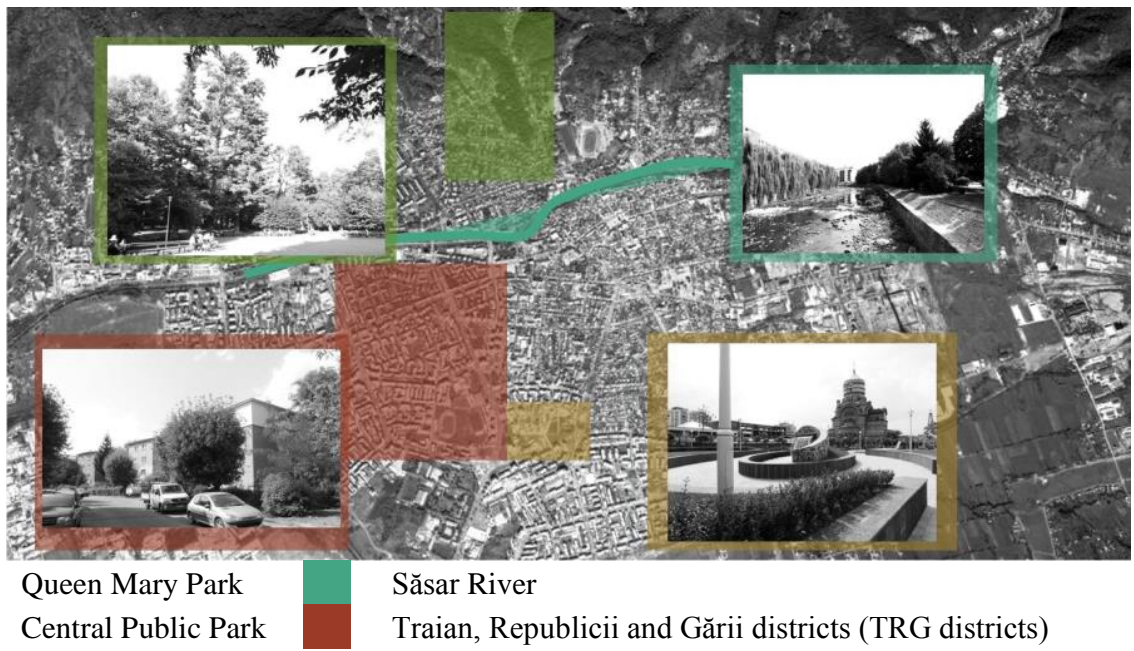

Figure 1. Demarcation of research sites 
Table 1. Presentation of locations based on usage

\begin{tabular}{|c|c|c|c|c|c|}
\hline Name & $\begin{array}{c}\text { Year of } \\
\text { creation }\end{array}$ & Size & Purpose & Current use & Age-group \\
\hline $\begin{array}{l}\text { Queen } \\
\text { Mary Park }\end{array}$ & $\begin{array}{l}\text { Mid-19th } \\
\text { century }\end{array}$ & $50.350 \mathrm{~m}^{2}$ & $\begin{array}{l}\text { urban } \\
\text { public park }\end{array}$ & $\begin{array}{l}\text { daily use of sports } \\
\text { facilities, the rate of } \\
\text { attendance increases } \\
\text { in the weekends, } \\
\text { when it is used for } \\
\text { recreation and } \\
\text { leisure }\end{array}$ & all age-groups \\
\hline $\begin{array}{l}\text { The banks } \\
\text { of the } \\
\text { Săsar } \\
\text { River }\end{array}$ & the $1970 \mathrm{~s}$ & $45.650 \mathrm{~m}^{2}$ & - & $\begin{array}{l}\text { due to river } \\
\text { regulations, it } \\
\text { cannot be used for } \\
\text { recreation in its full } \\
\text { length }\end{array}$ & - \\
\hline $\begin{array}{l}\text { Central } \\
\text { Public } \\
\text { Park }\end{array}$ & 2015 & $39.496 \mathrm{~m}^{2}$ & $\begin{array}{l}\text { urban } \\
\text { public park }\end{array}$ & $\begin{array}{l}\text { strong playground } \\
\text { orientation, } \\
\text { intensive use in the } \\
\text { afternoon }\end{array}$ & $\begin{array}{l}\text { mostly parents } \\
\text { with young } \\
\text { children, } \\
\text { senior } \\
\text { population }\end{array}$ \\
\hline $\begin{array}{l}\text { Traian, } \\
\text { Republicii } \\
\text { and Gării } \\
\text { districts } \\
\end{array}$ & $1950-1980$ & - & $\begin{array}{l}\text { residential } \\
\text { complex }\end{array}$ & $\begin{array}{l}\text { amateur gardeners } \\
\text { or people wanting to } \\
\text { work out }\end{array}$ & $\begin{array}{l}\text { senior } \\
\text { population }\end{array}$ \\
\hline
\end{tabular}

\section{a. Queen Mary Park (RO: Parcul Regina Maria)}

The quality of town parks affects the frequency and length of visits. The town park contributes to and supports the development of social relations around the town centre [8]. Individual surveys [9], however, have also shown that in addition to the availability of green spaces the state of the park or public space is also important for the visitors. In the case of Baia Mare, we are talking about the oldest green space, the original function of which was to provide a space for entertainment and meeting for the citizens of the town. It is characterized by its functions it had at the end of the $19^{\text {th }}$ and the beginning of the $20^{\text {th }}$ century: it features a pub that was turned into a restaurant, space for dancing, a lake, shady park benches, flower house, shooting range, and then tennis courts, a small railway, playgrounds, newer restaurants, running tracks, and dog tracks. In the $19^{\text {th }}$ century, the Liget ("grove") of Baia Mare was used both by noblemen and ordinary people (with different social status) at the same time [10].

Currently, the city park still has most of the old trees - it is in some way similar to a forest; the site seems functionally overloaded and overcrowded. From a utilization point of view, the playground and the small railway as well as the area around the improvised amusement park are highly popular among families with young children, while teenagers and those who prefer to work out use the northern 
part of the park, which is closer to the nature and is less structured, which, however, is more difficult or impossible to access during the rainy season and is even potentially dangerous.

\section{b. The banks of the River Săsar}

The town's hydrographic network is based on the River Săsar, flowing from east to west. It was a key element in the founding of the town: this is supported by the existence of mills built on the riverfront found in the first military survey. Later on, in the $20^{\text {th }}$ century, the number of mills somewhat decreased, but the baths along the river occupied a growing area, while the different points of the river and the mill races were a cheaper option for bathing.

In the 1970s, the river was regulated throughout the town, and the population had no access to the river. Although sections of higher altitude have green areas (poor use of plants, unattractive), they are used for transit or for dog-walking, and the most important conditioning effect is not stressed.

\section{c. Central Public Park (RO: Parcul Public Central)}

The newly built public park opened in 2015 is located in the southern part of Baia Mare, somewhat peripheral but near the residential complexes. Its original purpose is to serve as a public park for the strengthening of social ties, resting and recreation, education. The most valuable element of the park is Géza Vida's cactus collection including 6,000 pieces, which extends the attraction of the park. The most important element of the park is the playground. Regardless of the size of the young trees, the park is rather museum-like and sterile. From the point of view of landscape design, plant placement, and use, it is poor; there are less used corners, such as the labyrinth, which is not suitable for public parks. A public park that does not apply a close-to-nature approach is rather a public space.

d. Green spaces of residential complexes

Collective housing in Baia Mare is grouped into the following districts: Traian, Republicii, Gării, Progresului, partly V. Alecsandri and Săsar. Collective housing is built on a total of 257.78 hectares, which is $7.23 \%$ of the total urban area. Most of the buildings in the town are $\mathrm{P}+3-4$ floors, the highest ones do not exceed $\mathrm{G}+9$ levels.

After 1947, as the new Romanian socialist state engaged in large industrialization projects that ranged from enormous steel plants to mass housing estates for the newly urbanized workers, the problem of monotony and anonymity and overall foreignness of these new environments arose from the very start. Industrial work and its products (architecture being one of them) were seen at once as key to socialism, but also as potentially dehumanizing. [11] 
The construction of large buildings to house the crowds moving to the town from villages was carried out in several stages in Baia Mare. While in the 1950s the buildings were concentrated around the city centre and were up to 2 floors, starting from the second half of the 60s, the effects of socialism could be felt throughout the nation: the airport, the new railway station, and the bus station were built. The massive and foreign destruction of the traditional image of the small town was carried out from the late 60s to the late 80s. The population of Baia Mare increased considerably during the industrialization period: between the 1966 and the 1977 census, this meant a $150 \%$ increase; and the same growth can be seen between 1977 and 1992. Typically, former village dwellers settled down in the town, bringing along their customs and traditions. As a result, the unique use of green spaces in the residential complexes built under the communist regime in Romania resembles that of the village gardens. However, the setting up of vineyards, the planting of fruit trees and vegetables do not bring any benefit to the owners, giving the complexes a decomposed, incoherent image. The rebuilding and transformation of residential complexes due to industrialization, the lack of social activities, and functional segregation entail the need for stimulation.

It is a common practice in Romania, and thus in Baia Mare, that the green spaces around apartment buildings are maintained and beautified by the inhabitants, which has led most frequently to constant bickering and a chaotic scenery (Fig. 2.), but to neglect as well, and the few green spaces that would make living in communist residential communities a bit more bearable are a nuisance for public administration itself. Another problem that is present across the country is the issue of the chaotically built garages, which are always located on free surfaces, typically on green spaces. The sight of residential complexes is a sad picture at the moment.
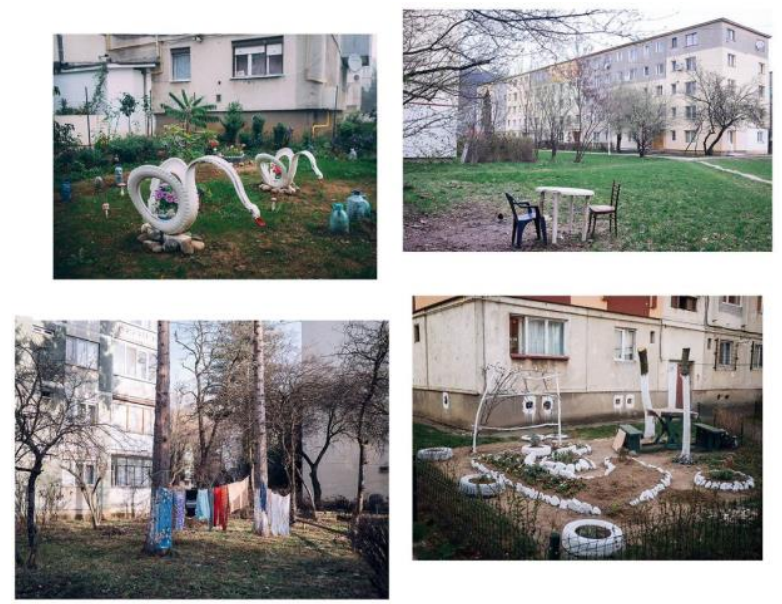

Figure 2. The issue of the use of green spaces in residential complexes. There are extremes, but not scattered, and they are typical of all Romanian towns. (photos by Tamás Hajdu) 
"Residents in high-density neighbourhoods differ in two important ways from their lower-density counterparts: they live in much closer proximity to their neighbours and they are more likely to have to share built features and facilities (Easthope \& Judd, 2010) such as open spaces and property maintenance services" [12]. It can be observed in the case of several residential complexes that if they have any type of public or even limited public free spaces, the atmosphere is more intimate, more homely, and it helps the inhabitants get to know each other better. At the same time, the spaces in the residential complexes are subject to a more strict supervision and collective responsibility, and that is why they are more protected [13].

\section{The issue of plant usage}

The implications for urban greenspace design are considerable. Dramatic displays of flower colour enhance most people's aesthetic experience in the short term, yet psychological restoration is more likely afforded by "background" green planting. This indicates that green planting has real value outside the relatively narrow flowering window of most species. [14]

Helen Hoyle and her colleagues found that moderate, and a design closer to nature has a more enhanced psychologically strengthening effect than over-designed, less natural spaces. At the same time, it is considered acceptable for the population of the UK to use natural, meadow-like designs, which would enhance the benefits of pollination; however, this kind of planning needs to be developed and promoted. Trees also have an interesting attraction value "[...] the presence of trees has an important impact on public housing residents' use of outdoor spaces. Trees are an important variable in creating sociopetal outdoor spaces - spaces that attract people to them" [15]; this, however, needs the selection of the suitable species.

Another problem is the decrease of the proportion of decorative plantings occurring in public spaces and parks, including the lack of use of perennial ornamental plants, a practice that significantly depletes the ecologically possible plant selection [16]. In the case of urban green spaces in Baia Mare, but also in other towns in Romania, it can be observed that they prefer to use annual plants, creating a kind of tradition. Unfortunately, annual plants are preferred over perennials. 


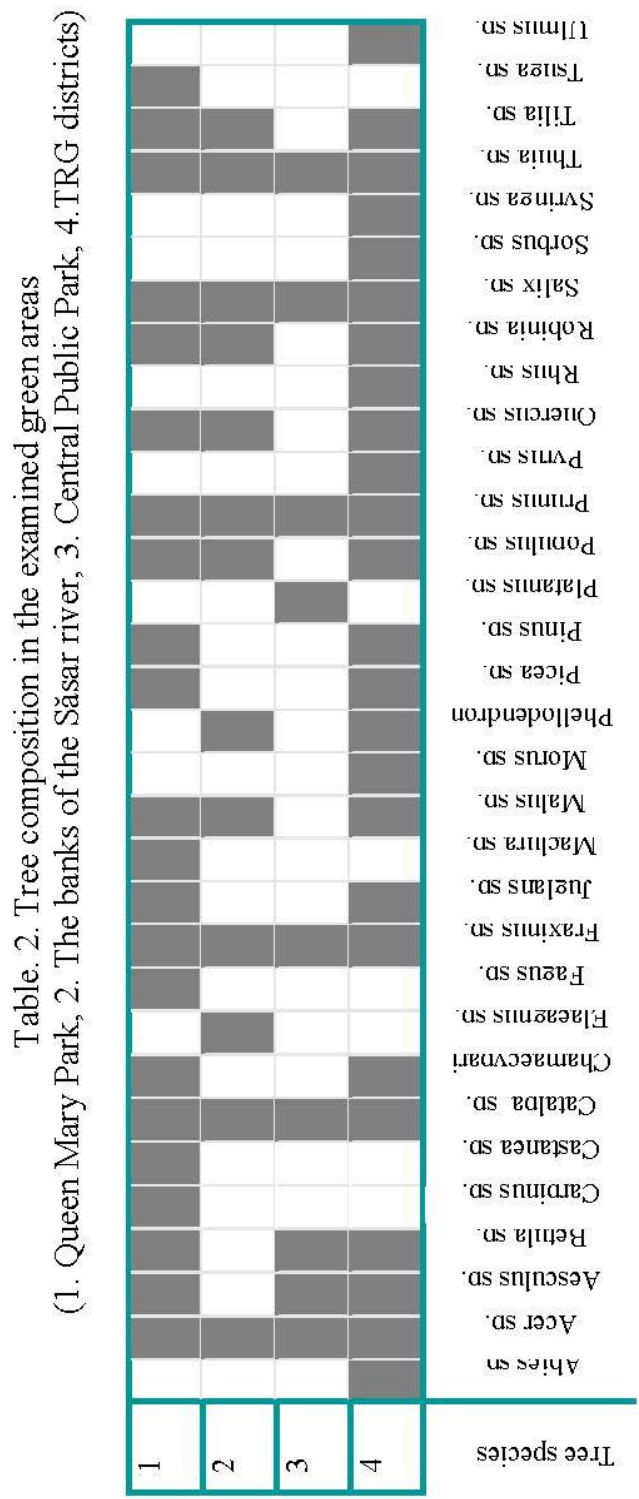

The study of the plants in public areas of Baia Mare can be summarized as follows:

the richness of species in green areas created in the past (in this case in the $19^{\text {th }}$ century) is much higher, although ornamental trees are much easier to find now, and the choice is significantly larger; 
$>$ in the case of creating new green spaces, more emphasis is placed on constructed elements, while ornamental plants are secondary and are used only for decorative purposes with requirements of intensive maintenance;

$>$ the residential complexes show a greater richness of species due to their private-garden character (the use of perennials and vegetables); these, however, are chaotically designed;

$>$ the poorness of species results in low stimulation and a monotonous image of the town;

$>$ it would be necessary to introduce new, mainly woody species suitable for urban settings by reforming the existing use of plants.

\section{Solutions}

\section{a. Creative city}

Good city-making is about maximizing assets and what is considered an urban asset has broadened dramatically. Urban assets and resources can be: hard, material and tangible, or soft, immaterial and intangible; real and visible, or symbolic and invisible; countable, quantifiable and calculable, or to do with perceptions and images. [17]

Vitality is the energy of the town that is needed to achieve viability. Creativity works as a vitality catalyst. Through lasting, viable, and sustainable innovation, a town's vitality can be helped in the long run. Forms of vitality and viability: economic, social, environmental, and cultural; at the same time - in connection with the previous ones -, there are nine criteria that help a town to be viable from the point of view of creativity: critical mass, diversity, accessibility, safety and security, identity, innovation, cooperation, competitiveness, and organizational skills [18].

Animated cities have spaces that allow for the creation of lively social connections as opposed to cities where the stability of social activities could not be maintained despite brilliant architectural works [19].

Low-stimulus environments are bleak. Sustainability has social aspects (health, well-being), environmental aspects (the protection of biological diversity by improving ecological aspects), and economic considerations (asset value growth) [20].

\section{b. Urban acupuncture and pocket gardens}

Since the economic crisis, it has become increasingly difficult to create new spaces or to implement larger-scale plans that would provide a solution to revitalize 
a district of the town; thus, the role of smaller interventions, which are targeted primarily at public areas, has increased significantly. There is a big difference between various types of projects and problem solving; the smallest ones, such as the planting of trees in an open space, would increase the quality of life of the people in its immediate neighbourhood [21].

According to Jamie Lerner [22], small initiatives and quick interactions can invigorate certain abandoned or neglected parts of the town, make them peoplecentred and sustainable. These transformations are not only physical: they have psychological and cultural effects as well and can function as incentives for the different age-groups. In every case, the goal is the people-centred approach, and this is especially important regarding the towns that endured communism. Good acupuncture interventions help understand the town, can heal man-made wounds in the landscape, practically trying to find a cure for human errors. Its main aim is to restore the cultural identity of a place or community, to add missing urban functions, to strengthen national identity, and to transfer formal iconic places to contemporary urban life, but it does not necessarily require large structural interventions.

It is important to make public spaces dynamic, to encourage art and the young generation. However, the inclusion of a river or channel into the life of a town, the revitalization of an existing green space or the creation of new green spaces, or even planting trees in the streets can be considered urban acupuncture.

Another possible solution in Baia Mare is the Pocket Park as defined by Francesco Armato:

Pocket Park, small areas that can make up for the emptiness, abandonment and no function of many spaces that are located within our cities, triggering processes of urban regeneration through the discovery of a new "life" and a new potentiality to accommodate. This must be rediscovered and brought to light so as to realize and perceive a different urban imaginary. [23]

This is a product that primarily plays a social role, strengthens relationships between people, or, depending on the nature of its design, it can emphasize the beneficial effects of nature on people (an oasis that provides the experience of being close to nature or pocket parks functioning as community gardens). The above mentioned park types would be the most ideal solution to the problems encountered in the residential complex in Baia Mare. Promoting correct gardening as recreational and social activity would covertly serve social purposes around apartment buildings. Many seniors choose to garden mainly for this reason and not for the products of cultivation. At the same time, the gardeners of apartment buildings are involved in shaping the street image 


\section{c. Promoting and establishing a forest park}

From existing forests, it is practical to create and cultivate areas that are close to natural forests, are diverse, mixed, and have a good traffic connection with the settlement. To this end, the northern part of Baia Mare, which is practically merged with the forest, would provide a perfect basis.

According to some studies, the amount of oxygen needed for daily respiration is produced by 10-20 trees (depending on the species) of grown foliage; if we break down this value to the size of the towns, it is incorrect to state that urban parks and gardens are "the lungs" of the settlement as the regeneration of air happens outside the town, and thus air exchange between the town and the neighbouring areas needs to be endured by the vegetation [24].

\section{Conclusion}

This work highlights the problems of green spaces of Baia Mare, problems that are not isolated but generally characterize the green spaces of Romania's settlements. As a solution, it is essential to create new open spaces that contribute to the socio-cultural development of green spaces so that it is not seen as a public space decorated with plants but as a public, reassuring, and attractive site. As urban ecosystems are labile and have little self-regulation capacity, social processes determine their development - so, they need proper and continuous regulation.

In Romania, and in Baia Mare too, urban green spaces have "grown up" to a stage where the arbitrary planning of the local government is replaced by a design that accommodates the needs of the population. It is important to utilize the power of green spaces to build human relations as well as a quality design, as "badly designed and badly managed public spaces are often blamed for uncivil behaviour and increased (fear of) crime" [25].

Other open space typologies that have a sociocultural perspective emphasize the potentials of interaction for different parts of society. Spatial typologies that include a more political economic perspective deal predominantly with aspects of ownership and the management of specific open spaces [26]. "In reality, physical form will impact decisively on the socio-economic potential of space, just as the socio-economic context should always inform any design solution adopted" [27].

Small-scale but effective interventions of civil initiatives are needed, but the design and maintenance of town planning and urban green spaces should be sufficiently open and collaborative so that competitive and sustainable green spaces can be created. 


\section{References}

[1] Kabisch, N., Qureshi, S., Haase, D. (2015), Human-environment interactions in urban green spaces - a systematic review of contemporary issues and prospects for future research. Environmental Impact Assessment Review (50), 25-34.

[2] Kabisch, N., Strohbach, M., Haase, D., Kronenberg, J. (2016), Urban green space availability. European Cities in Ecological Indicators (70), 586-596.

[3] Mattijssen, T. J. M., van der Jagt, A. P. N., Buijs, A. E., Elands, B. H. M., Erlwein, S., Lafortezza, R. (2017), The long-term prospects of citizens managing urban green space: from place making to place-keeping? Urban Forestry \& Urban Greening (26), 78-84.

[4] Baycan Levent, T., Vreeker, R., Nijkamp, P. (2004), Multidimensional evaluation of urban green spaces: a comparative study on European cities. https://www.researchgate.net/ publication/4795787_Multidimensional_Evaluation_of_Urban_Green_Spaces_A_Comparative _Study_on_European_Cities.

[5] Gehl, J. (2011), Viața între clădiri. Utilizările spațiului public. Bucharest: Igloo Media, 9-10.

[6] Dempsey, N., Brown, C., Bramley, G. (2012), The key to sustainable urban development in UK cities? The influence of density on social sustainability. Progress in Planning 77(3), 89-141.

[7] General Urban Plan Baia Mare: http://www.baiamare.ro/ro/Administratie/Administratia-PublicaLocala/PUG/Regulamentul-Local-de-Urbanism--PUG/.

[8] Kaźmierczak, A. (2013), The contribution of local parks to neighbourhood social ties. Landscape and Urban Planning (109), 31-44.

[9] Kothencz, Gy. (2015), Szegedi parkok életminőség-befolyásoló hatásainak elemzése látogatói vélemények alapján. Területi statisztika 55(4), 370-379.

[10] Metz, J., Oszóczki, K., Soltz, L. (1993), Nagybányai kalauz. Baia Mare: Misztótfalusi Kis Miklós Közmüvelődési Egyesület.

[11] Maxim, J. (2017), Building the collective: theories of the archaic in socialist modernism, Romania circa 1958. Rethinking Marxism: a Journal of Economics, Culture \& Society 29(1), 45.

[12] Dempsey, N., Brown, C., Bramley, G. (2012), The key to sustainable urban development in UK cities? The influence of density on social sustainability. Progress in Planning 77(3), 97.

[13] Gehl, J. (2011), Viața între clădiri. Utilizările spațiului public. Bucharest: Igloo Media, 59.

[14] Hoyle, H., Hitchmough, J., Jorgensen, A. (2017), All about the 'wow factor'? The relationships between aesthetics, restorative effect and perceived biodiversity in designed urban planting. Landscape and Urban Planning 164, 109-123.

[15] Levine Coley, R., Kou, F. E., Sullivan, W. C. (1997), Where does community grow? The social context created by nature in urban public housing. Environment and Behavior 29(4), 468-494.

[16] Gerzson, L., Szabó, K., Bede-Fazekas, Á. (2012), Újszerü növényalkalmazási lehetőségek épített környezetben. Dendrológiai kutatások a Kert- és Szabadtértervezési Tanszéken (20082011). Fenntartható fejlödés, élhetö régió, élhetö települési táj. Budapesti Corvinus Egyetem, Budapest, 87-98.

[17] Landry, C. (2008), The creative city: a toolkit for urban innovators. Comedia, UK.

[18] Landry, C. (2008), The creative city: a toolkit for urban innovators. Comedia, UK.

[19] Gehl, J. (2011), Viața între clădiri. Utilizările spațiului public. Bucharest: Igloo Media.

[20] Wandl, A., Rooij, R., Rocco, R. (2017), Towards sustainable territories-in-between: a multidimensional typology of open spaces in Europe. Planning Practice \& Research, 55-84.

[21] Prins, N. (2013), Urban acupuncture: creating a method to strategically apply and design small-scale interventions. MSc thesis. Available at: http://www.library.tudelft.nl/collecties/tudelft-repository/.

[22] Lerner, J. (2014), Urban acupuncture. Island Press, Washington. 
[23] Armato, F. (2017), Pocket park: product urban design. The Design Journal - an International Journal for All Aspects of Design. Available at: http://www.tandfonline.com/doi/abs/10.1080/14606925.2017.1352705.

[24] Jámbor, I. (2002), A települések zöldfelülete. Budapesti Corvinus Egyetem, Táképítészeti Kar, Kert- és Településépítészeti Tanszék, Budapest.

[25] Wandl, A., Rooij, R., Rocco, R. (2017), Towards sustainable territories-in-between: a multidimensional typology of open spaces in Europe. Planning Practice \& Research, 55-84.

[26] Wandl, A., Rooij, R., Rocco, R. (2017), Towards sustainable territories-in-between: a multidimensional typology of open spaces in Europe. Planning Practice \& Research, 55-84.

[27] Carmona, M. (2014), The place-shaping continuum: a theory of urban design process. Journal of Urban Design 19(1), 2-36. 